\title{
Adiponectin inhibits palmitate-induced apoptosis through suppression of reactive oxygen species in endothelial cells: involvement of cAMP/protein kinase A and AMP-activated protein kinase
}

\author{
Ji-Eun Kim ${ }^{1,2}$, Seung Eun Song ${ }^{1,2}$, Yong-Woon Kim ${ }^{1}$ Jong-Yeon Kim ${ }^{1}$, Sung-Chul Park ${ }^{3}$, Yoon-Ki Park ${ }^{3}$, \\ Suk-Hwan Baek ${ }^{2,4}$, In Kyu Lee ${ }^{5}$ and So-Young Park ${ }^{1,2}$ \\ ${ }^{1}$ Department of Physiology, ${ }^{2}$ Aging-associated Vascular Disease Research Center, ${ }^{3}$ Department of Obstetrics and Gynecology and ${ }^{4}$ Department of Biochemistry \\ and Molecular Biology, College of Medicine, Yeungnam University, Daegu 705-717, South Korea \\ ${ }^{5}$ Department of Internal Medicine, Kyungpook National University School of Medicine, Daegu 700-721, South Korea \\ (Correspondence should be addressed to S-Y Park at Department of Physiology, College of Medicine, Yeungnam University; Email: sypark@med.yu.ac.kr)
}

\begin{abstract}
The present study examined whether adiponectin can inhibit palmitate-induced apoptosis, and also the associated mechanisms and signal transduction pathways in human umbilical vein endothelial cells. Cells treated with $500 \mu \mathrm{M}$ palmitate for $48 \mathrm{~h}$ increased reactive oxygen species (ROS) generation and induced apoptosis. Treatment with antioxidant $\mathrm{N}$-acetyl-L-cysteine $(1 \mathrm{mM})$ and globular adiponectin $(5 \mu \mathrm{g} / \mathrm{ml})$ inhibited palmitate-induced ROS generation and apoptosis. The AMP-activated protein kinase (AMPK) activator 5-aminoimidazole-4-carboxamide-1- $\beta$-D-ribofuranoside (AICAR; $1 \mathrm{mM}$ ), and cAMP activators forskolin $(10 \mu \mathrm{M})$ and cholera toxin $(200 \mathrm{ng} / \mathrm{ml})$ also displayed the same effects. The inhibitory effects of adiponectin on ROS generation and apoptosis were reversed by the AMPK
\end{abstract}

inhibitor compound C $(40 \mu \mathrm{M})$, cAMP inhibitor SQ22536 $(50 \mu \mathrm{M})$, and protein kinase A (PKA) inhibitor H-89 $(10 \mu \mathrm{M})$. The inhibitory effect of forskolin on palmitateinduced apoptosis was reversed by compound $\mathrm{C}$, whereas the inhibitory effect of AICAR was not reversed by SQ22536 and H-89. AICAR and forskolin could not inhibit palmitate-induced apoptosis in cells treated with dominantnegative AMPK. Forskolin increased phosphorylated AMPK at both Thr-172 and Ser-485/491. These results suggest that adiponectin inhibits palmitate-induced apoptosis by suppression of ROS generation via both the cAMP/PKA and AMPK pathways. Interaction between cAMP/PKA and AMPK pathways may be involved.

Journal of Endocrinology (2010) 207, 35-44

\section{Introduction}

Adiponectin is an abundant adipocyte-derived plasma protein that exerts beneficial effects on insulin sensitivity and vascular function (Matsuzawa 2005). Plasma adiponectin levels are decreased in obese/diabetic rodents and humans (Haluzik et al. 2004), and adiponectin knockout mice fed a high-fat diet exhibit severe insulin resistance (Maeda et al. 2002). Low adiponectin levels are also associated with vascular dysfunction (Tan et al. 2004), and adiponectin treatments are beneficial for atherosclerosis and endothelial cell dysfunction (Ouchi et al. 2001, Arita et al. 2002). The anti-atherosclerotic effect of adiponectin involves suppression of the proliferation of smooth muscle cells (Arita et al. 2002), inhibition of macrophage transformation to form cells (Ouchi et al. 2001), and reduced inflammatory responses in endothelial cells (Kougias et al. 2005). The beneficial effects of adiponectin on endothelial cell function are mediated by an increase in nitric oxide synthesis and anti-apoptotic effect (Chen et al. 2003, Goldstein et al. 2008).

Apoptosis is a programmed cell death pathway that is essential for tissue development and homeostasis, and is involved in down-regulating cell growth (Fulda \& Debatin 2006). Substantial in vivo and in vitro evidence indicate that apoptosis plays an important role in the pathophysiology of vascular dysfunction induced by various causes. Increased endothelial cell apoptosis can lead to vascular leak and exposure of a thrombogenic subendothelial matrix (Winn \& Harlan 2005). Furthermore, as apoptotic endothelial cells become proadhesive for procoagulants, they can promote coagulation (Winn \& Harlan 2005).

Elevated plasma-free fatty acid level is a common feature of both poorly controlled type 1 and type 2 diabetes (Shulman 2000, Boden \& Shulman 2002), and is associated with obesity and metabolic syndrome (Ruderman \& Saha 2006). One of the most common dietary fatty acids is palmitate (de Vries et al. 1997, Kong \& Rabkin 2000), 
a 16-carbon saturated fatty acid that induces apoptosis in many cell types including endothelial cells (Kim et al. 2008c).

The present study examined whether adiponectin inhibits palmitate-induced apoptosis in human umbilical vein endothelial cells (HUVECs). Furthermore, the mechanisms and signal transduction pathways in the adiponectin-mediated inhibition of apoptosis by palmitate were examined.

\section{Materials and Methods}

\section{Materials}

Globular adiponectin was purchased from Phoenix Pharmaceuticals (Phoenix, AZ, USA). Antibodies for the phosphorylated AMP-activated kinase (pAMPK), AMPK, phosphorylated extracellular-regulated kinase (pERK), ERK, phosphorylated-p38 (p-p38), p38, phosphorylated $\mathrm{N}$-Jun N-terminal kinase (pJNK), and JNK were obtained from Cell Signaling Technology (Danvers, MA, USA).

The cAMP activators cholera toxin $(\mathrm{CTx})$ and forskolin, and cAMP inhibitor SQ22536 were purchased from Biomol International (Plymouth Meeting, PA, USA), and palmitic acid, 3-[4,5 dimethylthiazol-2-yl]-2,5-diphenyl tetrazolium bromide thiazolyl blue (MTT), and $N$-acetyl-L-cysteine (NAC) were obtained from Sigma-Aldrich. The AMPK activator AICAR was purchased from Toronto Research Chemicals (North York, ON, Canada), and the AMPK inhibitor compound C, JNK inhibitor, p38 inhibitor SB203580, and ERK inhibitor PD98059 were from Calbiochem (San Diego, CA, USA). Protein kinase A (PKA) inhibitor H-89 was from Stressgen (Victoria, BC, Canada), collagenase type II was from Worthington Biochemical Corporation (Freehold, NJ, USA), and enhanced chemiluminescence (ECL) reagent was from Amersham Biosciences.

\section{HUVECs culture}

HUVECs were isolated from human umbilical cords collected from normal deliveries at Yeungnam University. A signed consent was obtained, and the study was approved by the Institutional Review Board of Yeungnam University Medical Center. Vein in cord was washed with prewarmed PBS using a $50 \mathrm{ml}$ syringe and then filled with Hanks' balanced salt solution (HBSS) containing 0.2\% collagenase type II. After $15 \mathrm{~min}$, HBSS was collected into a tube and centrifuged at $700 \mathrm{~g}$ for $5 \mathrm{~min}$. Isolated cells were planted in $100 \mathrm{~mm}$ diameter culture dishes coated with $0 \cdot 1 \%$ gelatin (SigmaAldrich), and cultured in M199 containing 10\% fetal bovine serum and $1 \%$ antibiotics. The cells were grown at $37^{\circ} \mathrm{C}$ in a humidified atmosphere with $5 \% \mathrm{CO}_{2}$. The cells planted on the culture dish were regarded as passage 0 , and the cells from passages 3 to 4 were used.

\section{Cell viability}

The MTT assay was conducted as described previously (Kim et al. 2008b). Briefly, the MTT was dissolved in PBS at a concentration of $5 \mathrm{mg} / \mathrm{ml}$ and sterilized by passage through a $0.22 \mu \mathrm{m}$ filter. Cells were seeded in wells of a 24 -well plate containing $250 \mu \mathrm{l}$ of the culture medium, and $25 \mu \mathrm{l}$ MTT stock solution were then added to each well. After incubation for $4 \mathrm{~h}$ at $36.5^{\circ} \mathrm{C}, 300 \mu \mathrm{l}$ of a dimethyl sulfoxide solution were added to all of the wells and mixed thoroughly to lyse the cells and dissolve the dark blue crystals. After $5 \mathrm{~min}$, $100 \mu \mathrm{l}$ of the lysis solution were transferred to a well of a 96-well plate, and the absorbance was read on a microplate reader at a wavelength of $550 \mathrm{~nm}$.

\section{Cell apoptosis}

Cell apoptosis was assessed by caspase- 3 activity and annexin V staining. Caspase- 3 activity was measured using a Caspase- 3 Colorimetric Assay kit (R\&D Systems, Minneapolis, MN, USA) according to the manufacturer's instructions. This method is based on the hydrolysis of the peptide substrate acetyl-Asp-Glu-Val-Asp p-nitroanilide by caspase-3, resulting in the release of the $p$-nitroaniline moiety. The production of $p$-nitroaniline was measured at $405 \mathrm{~nm}$ using a plate reader. Annexin V staining was measured using a flow cytometer according to the manufacturer's instructions (BD Bioscience, San Jose, CA, USA). Briefly, the cells in a 6-well plate were digested with $0.25 \%$ trypsin and then collected by centrifugation. The cells were washed twice with cold PBS and mixed with a $1 \times$ binding buffer. The cells $\left(1 \times 10^{5}\right.$ cells $/ 100 \mu \mathrm{l}$ binding buffer $)$ were transferred to a tube and then $5 \mu \mathrm{l}$ annexin V-FITC containing $0.01 \mathrm{M}$ HEPES $\mathrm{pH} 7 \cdot 4,0 \cdot 14 \mathrm{M} \mathrm{NaCl}$, and $2.5 \mathrm{mM} \mathrm{CaCl}$ were added. The mixture was incubated for $15 \mathrm{~min}$ at room temperature in the dark. After the addition of $400 \mu \mathrm{l}$ binding buffer, the level of annexin V-FITC conjugation was detected using the FL1 setting of the FACSCalibur (BD Bioscience).

\section{Reactive oxygen species generation}

The generation of reactive oxygen species (ROS) was measured using flow cytometry and live-cell microscopy. For flow cytometry, the cells $\left(3 \times 10^{5}\right.$ cells/well $)$ were incubated in $10 \mu \mathrm{M}$ carboxy- $2^{\prime}, 7^{\prime}$-dichlorodihydrofluorescein diacetate (carboxy- $\mathrm{H}_{2}$ DCFHDA; Molecular Probes, Eugene, OR, USA) at $37^{\circ} \mathrm{C}$ for $20 \mathrm{~min}$, harvested by trypsinization, and washed twice with cold PBS. Cells conjugated with carboxy- $\mathrm{H}_{2}$ DCFHDA-FITC (excitation, 494; emission, $524 \mathrm{~nm}$ ) were detected by using the FL1 setting of the FACSCalibur (BD Bioscience). For live-cell microscopy, the cells were washed two times with PBS and were incubated in sodium acetate-free medium containing $10 \mu \mathrm{M}$ peroxide-sensitive fluorescent dye $\mathrm{H}_{2}$ DCFHDA (Molecular Probes) for $1 \mathrm{~h}$ in the dark. After the incubation medium was aspirated, the cells were washed with PBS and 
placed in medium without sodium acetate. Intracellular fluorescence was monitored using a temperature-regulated $\left(37^{\circ} \mathrm{C}\right)$, live-cell microscope (Leika, Wetzlar, Germany). Cells treated with $1 \mathrm{mM}$ hydrogen peroxide $\left(\mathrm{H}_{2} \mathrm{O}_{2}\right)$ for $1 \mathrm{~h}$ were used as a positive control.

\section{cAMP assays}

The cells $\left(2 \times 10^{5}\right.$ cells/well) were seeded in wells of a $24-$ well plate. After experimental treatment, the incubation medium was aspirated. The cells were lysed by $200 \mu \mathrm{l} 0 \cdot 1 \mathrm{M} \mathrm{HCl}$ containing $0 \cdot 1 \%$ Triton $\mathrm{X}-100$, and the lysis solution was transferred into microcentrifuge tubes. After centrifugation at $1300 \mathrm{~g}$ for $5 \mathrm{~min}$ at room temperature, cellular cAMP concentrations in the supernatants were determined with a direct enzyme immunoassay kit (Amersham Biosciences) as described by the manufacturer.

\section{Western blotting}

The cells were harvested by trypsinization, washed in PBS, and resuspended in a lysis buffer (Invitrogen) containing 1\% NP40, $150 \mathrm{mM} \mathrm{NaCl}, 5 \mathrm{mM} \mathrm{MgCl}, 10 \mathrm{mM}$ HEPES buffer, leupeptin, and pepstatin A. Protein concentration was determined by the Bradford method (Bio-Rad Laboratories). A $30 \mu \mathrm{g}$ sample of the total protein per lane was separated by $10 \%$ SDS-PAGE. The separated proteins were then transferred to a $0.45 \mu \mathrm{m}$ polyvinylidene fluoride membrane (Gelman Sciences, Ann Arbor, MI, USA). After blocking with a solution containing $5 \%$ skim milk/10 mM Tris- $\mathrm{HCl}$, $\mathrm{pH} 7 \cdot 4 / 150 \mathrm{mM} \mathrm{NaCl} / 0 \cdot 1 \%$ Tween 20 , the membrane was incubated overnight at $4{ }^{\circ} \mathrm{C}$ with a 1:1000 dilution of the primary antibody. Specific antibody binding was detected using a 1:2000 dilution of sheep anti-rabbit IgG HRP (Santa Cruz Biotechnology, Santa Cruz, CA, USA) for $1 \mathrm{~h}$ at room temperature and visualized using an ECL detection reagent (Amersham Biosciences).

\section{Transfection of dominant-negative AMPK $\alpha 1$ and $\alpha 2$}

Plasmids encoding c-Myc-tagged forms of dominantnegative AMPK (DN-AMPK) $\alpha 1$ and $\alpha 2$ mixture were provided by Dr J Ha (Department of Molecular Biology, Kyung Hee University College of Medicine, Seoul, South Korea). Subconfluent HUVECs were incubated with adenoviruses expressing $\beta$-galactosidase or DN-AMPK (Ad-DN-AMPK) at a concentration of 100 plaque-forming units per cell for $1 \mathrm{~h}$ at $37^{\circ} \mathrm{C}$ in DMEM without serum as described previously (Lee et al. 2003, 2005, Kim et al. 2008a).

\section{Statistical analysis}

The results are expressed as the mean \pm S.E.M. The difference among groups was analyzed by ANOVA with a post-hoc analysis by a Duncan's multiple test. A $P$ value $<0.05$ was considered significant.

\section{Results}

\section{Palmitate induces apoptosis through ROS}

Palmitate at 250 and $500 \mu \mathrm{M}$ decreased cell viability by 12 and $35 \%$ respectively over $48 \mathrm{~h}$ (Fig. 1A). Palmitate treatment for $48 \mathrm{~h}$ increased cell apoptosis in a dose-dependent manner as measured by caspase- 3 activity $(1 \cdot 3-$ and $2 \cdot 5$-fold of the control at 250 and $500 \mu \mathrm{M}$ palmitate respectively; Fig. 1B). Annexin $\mathrm{V}$ staining also revealed that palmitate induced apoptosis in HUVECs (Fig. 1C).

Next, we tested whether ROS was involved in palmitateinduced apoptosis. Treatment of cells with $500 \mu \mathrm{M}$ palmitate or $1 \mathrm{mM} \mathrm{H}_{2} \mathrm{O}_{2}$ increased ROS generation as determined by live-cell microscopy and flow cytometry analysis (Fig. 1D and E). Pretreatment of cells with $1 \mathrm{mM}$ of antioxidant NAC significantly blocked palmitate-induced cell apoptosis as measured by caspase- 3 activity and annexin $\mathrm{V}$ staining (Fig. 2A and B), and blocked ROS generation by palmitate (Fig. 2C and D). These results suggest that palmitate induces apoptosis through the ROS generation in HUVECs.
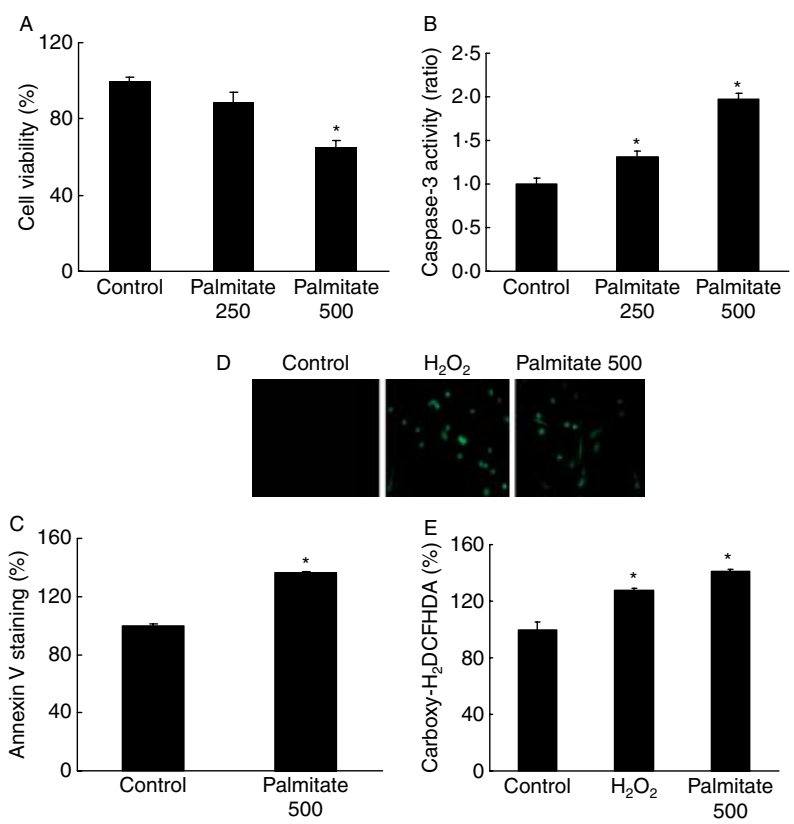

Figure 1 The effects of palmitate on cell survival, apoptosis, and ROS generation in human umbilical vein endothelial cells. Cells were treated with 250 or $500 \mu \mathrm{M}$ palmitate for $48 \mathrm{~h}$, and cell survival was determined by a MTT assay $(\mathrm{A})$. Cells were treated with 250 or $500 \mu \mathrm{M}$ palmitate for $48 \mathrm{~h}$, and cell apoptosis was determined by caspase- 3 activity (B) and annexin $V$ staining (C). Cells were treated with $500 \mu \mathrm{M}$ palmitate for $18 \mathrm{~h}$, and ROS was detected using $\mathrm{H}_{2}$ DCFHDA under microscope. Cells treated with $1 \mathrm{mM} \mathrm{H}_{2} \mathrm{O}_{2}$ were used as a positive control (D). Cells were treated with $500 \mu \mathrm{M}$ palmitate for $6 \mathrm{~h}$, and ROS was detected using carboxy- $\mathrm{H}_{2}$ DCFHDA with flow cytometry analysis. Cells treated with $1 \mathrm{mM} \mathrm{H}_{2} \mathrm{O}_{2}$ were used as a positive control (E). The results are reported as the mean \pm S.E.M. of three to five separate experiments. In each experiment, at least three samples were used. $* P<0 \cdot 05$ versus control. 

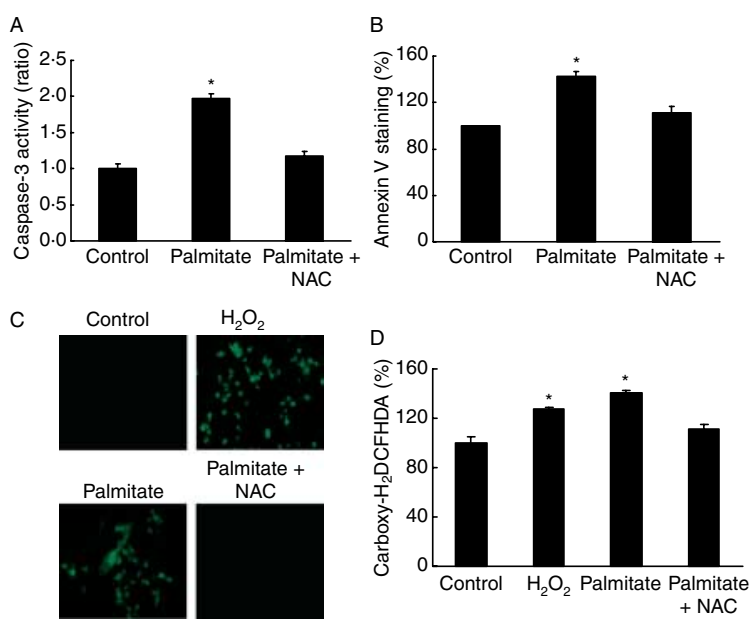

Figure 2 The effects of antioxidant $N$-acetyl-L-cysteine (NAC) on palmitate-induced ROS generation and apoptosis in human umbilical vein endothelial cells. Cells were pretreated with $1 \mathrm{mM}$ $\mathrm{NAC}$ for $1 \mathrm{~h}$ before exposure to $500 \mu \mathrm{M}$ palmitate for $48 \mathrm{~h}$, and then apoptosis was determined by caspase- 3 activity (A) and annexin- $\mathrm{V}$ staining (B). Cells were pretreated with NAC for 30 min before exposure to $500 \mu \mathrm{M}$ palmitate for $18 \mathrm{~h}$, and ROS was detected using $\mathrm{H}_{2}$ DCFHDA under microscope. Cells treated with $1 \mathrm{mM} \mathrm{H}_{2} \mathrm{O}_{2}$ were used as a positive control (C). Cells were pretreated with NAC for $30 \mathrm{~min}$ before exposure to $500 \mu \mathrm{M}$ palmitate for $6 \mathrm{~h}$, and ROS was detected using carboxy- $\mathrm{H}_{2}$ DCFHDA with flow cytometry analysis. Cells treated with $1 \mathrm{mM} \mathrm{H}_{2} \mathrm{O}_{2}$ were used as a positive control (D). The results are reported as the mean \pm S.E.M. of three to five separate experiments. In each experiment, at least three samples were used. ${ }^{*} P<0 \cdot 05$ versus control.

Adiponectin inhibits palmitate-induced apoptosis through suppression of ROS

The effect of adiponectin on palmitate-induced ROS generation and apoptosis was determined in HUVECs. Adiponectin exists in the circulation as a full-length protein and a putative proteolytic cleavage fragment consisting of the globular C-terminal domain that is pharmacologically active (Han et al. 2007). In this study, globular adiponectin was used at a concentration of $5 \mu \mathrm{g} / \mathrm{ml}$ (Motoshima et al. 2004). Treatment of cells with $500 \mu \mathrm{M}$ palmitate increased apoptosis by 2 -fold, and $5 \mu \mathrm{g} / \mathrm{ml}$ globular adiponectin blocked palmitate-induced apoptosis as determined by caspase-3 activity (Fig. 3A). Apoptosis determined by annexin $\mathrm{V}$ staining also showed the same result (Fig. 3B). Pretreatment of cells with $5 \mu \mathrm{g} / \mathrm{ml}$ adiponectin significantly inhibited the production of ROS as determined using live-cell microscopy (Fig. 3C) and flow cytometry analysis (Fig. 3D). These results suggest that adiponectin inhibits palmitate-induced apoptosis through the suppression of ROS generation.

\section{$A M P K$ is involved in adiponectin-mediated suppression of ROS and apoptosis}

The mechanisms of the suppressive effects of adiponectin on palmitate-induced apoptosis were investigated. First, the involvement of AMPK pathway in the adiponectin-mediated effect was determined, since adiponectin is known to activate this pathway. Treatment of cells with adiponectin for $1 \mathrm{~h}$ increased pAMPK (Fig. 4A) suggesting that adiponectin increases the activity of AMPK in HUVECs. Adiponectin and the AMPK activator AICAR $(1 \mathrm{mM})$ inhibited palmitateinduced apoptosis, and the suppressive effect of adiponectin on apoptosis was blocked by the AMPK inhibitor compound $\mathrm{C}(40 \mu \mathrm{M})$ as determined by caspase-3 activity and annexin V staining (Fig. 4B and C). The suppressive effect of adiponectin on ROS generation was also blocked by compound $\mathrm{C}$ as determined by live-cell microscopy and flow cytometry analysis (Fig. 4D and E). These results indicate that adiponectin can suppress palmitate-induced ROS generation and apoptosis through the AMPK pathway.

\section{cAMP/PKA is involved in adiponectin-mediated suppression of} ROS and apoptosis

Adiponectin is also known to activate cAMP/PKA pathway, and the involvement of this pathway on the inhibitory effect of adiponectin on palmitate-induced apoptosis was investigated. First, the activation of intracellular cAMP by adiponectin was determined. cAMP levels were increased
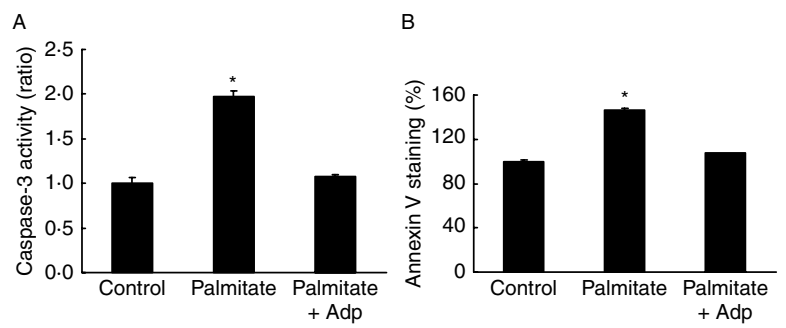

C
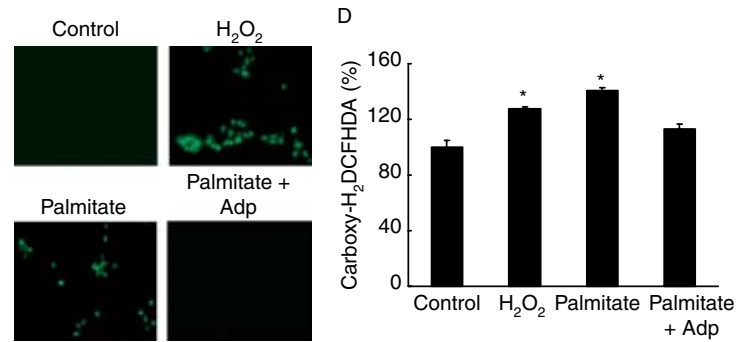

Figure 3 The effects of adiponectin on palmitate-induced ROS generation and apoptosis in human umbilical vein endothelial cells. Cells were pretreated with $5 \mu \mathrm{g} / \mathrm{ml}$ adiponectin (adp) before exposure to $500 \mu \mathrm{M}$ palmitate for $48 \mathrm{~h}$, and apoptosis was determined by caspase-3 activity (A) and annexin $V$ staining (B). Cells were pretreated with $5 \mu \mathrm{g} / \mathrm{ml}$ adiponectin for $30 \mathrm{~min}$ before exposure to $500 \mu \mathrm{M}$ palmitate for $18 \mathrm{~h}$, and ROS was detected using $\mathrm{H}_{2}$ DCFHDA under microscope. Cells treated with $1 \mathrm{mM} \mathrm{H}_{2} \mathrm{O}_{2}$ were used as a positive control (C). Cells were pretreated with $5 \mu \mathrm{g} / \mathrm{ml}$ adiponectin for $30 \mathrm{~min}$ before exposure to $500 \mu \mathrm{M}$ palmitate for $6 \mathrm{~h}$, and ROS was detected using carboxy- $\mathrm{H}_{2}$ DCFHDA with flow cytometry analysis. Cells treated with $1 \mathrm{mM} \mathrm{H}_{2} \mathrm{O}_{2}$ were used as a positive control (D). The results are reported as the mean \pm S.E.M. of three to five separate experiments. In each experiment, at least three samples were used. ${ }^{*} P<0 \cdot 05$ versus control. 

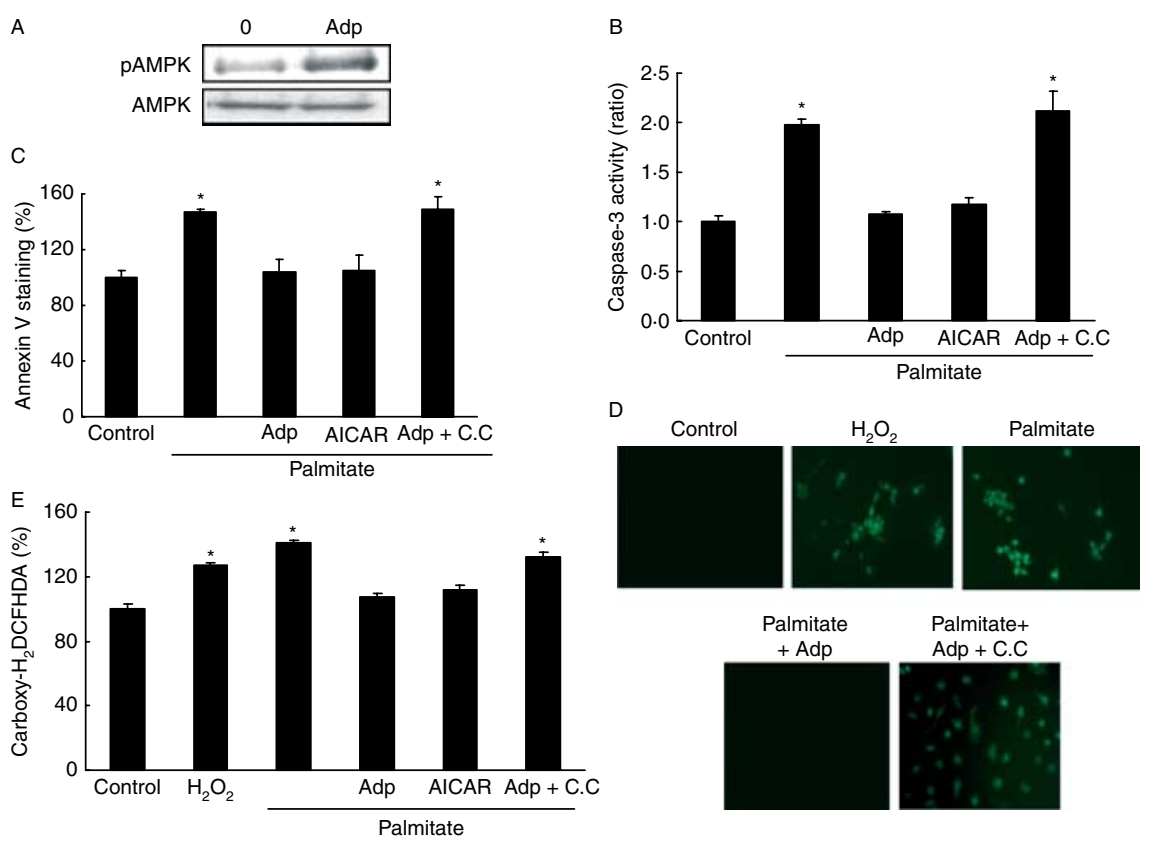

Figure 4 Involvement of AMPK pathway in the inhibitory effects of adiponectin on palmitateinduced ROS generation and apoptosis in human umbilical vein endothelial cells. Phosphorylation of AMPK at Thr-172 was measured in cells treated with $5 \mu \mathrm{g} / \mathrm{ml}$ adiponectin (adp) for $1 \mathrm{~h}$ by western blotting (A). Cells were treated with AMPK inhibitor compound C (C.C; $40 \mu \mathrm{M})$ for $1 \mathrm{~h}$, and then with adiponectin $(5 \mu \mathrm{g} / \mathrm{ml})$ or AMPK activator AICAR $(1 \mathrm{mM})$ for $1 \mathrm{~h}$ before exposure to $500 \mu \mathrm{M}$ palmitate for $48 \mathrm{~h}$. Cell apoptosis was determined by caspase-3 activity (B) and annexin V staining (C). Cells were treated with AMPK inhibitor compound C (C.C; $40 \mu \mathrm{M})$ for $30 \mathrm{~min}$, and then with adiponectin $(5 \mu \mathrm{g} / \mathrm{ml})$ for $30 \mathrm{~min}$ before exposure to $500 \mu \mathrm{M}$ palmitate for $18 \mathrm{~h}$. ROS was detected using $\mathrm{H}_{2}$ DCFHDA under microscope. Cells treated with $1 \mathrm{mM} \mathrm{H}_{2} \mathrm{O}_{2}$ were used as a positive control (D). ROS was detected using carboxy- $\mathrm{H}_{2}$ DCFHDA with flow cytometry analysis under the same experimental conditions as in (D) except for the incubation time of palmitate $(6 \mathrm{~h})$. Cells treated with $1 \mathrm{mM} \mathrm{H}_{2} \mathrm{O}_{2}$ were used as a positive control (E). The results are reported as the mean \pm s.E.M. of three to five separate experiments. In each experiment, at least three samples were used. ${ }^{*} P<0 \cdot 05$ versus control.

by adiponectin in a time-dependent manner. The level of cAMP increased at 12 and $24 \mathrm{~h}$ by adiponectin was comparable to that of cAMP activated by CTx $(200 \mathrm{ng} / \mathrm{ml})$ and forskolin $(10 \mu \mathrm{M}$; Fig. $5 \mathrm{~A})$. These results support the view that adiponectin functions as a cAMP activator. Treatment with $200 \mathrm{ng} / \mathrm{ml} \mathrm{CTx}$ and $10 \mu \mathrm{M}$ forskolin completely blocked palmitate-induced apoptosis as measured by caspase- 3 activity and annexin $\mathrm{V}$ staining (Fig. $5 \mathrm{~B}$ and $\mathrm{C}$ ). The cAMP inhibitor SQ22536 $(50 \mu \mathrm{M})$ and PKA inhibitor H-89 $(10 \mu \mathrm{M})$ reversed the suppressive effect of adiponectin on palmitate-induced apoptosis (Fig. 5B and C). Treatment of cells with adiponectin and forskolin reduced ROS generation by palmitate as assessed using live-cell microscopy and flow cytometry analysis (Fig. 5C). H-89 reversed the suppressive effect of adiponectin on palmitate-induced ROS generation (Fig. 5D). These results support the suggestion that cAMP/PKA pathway is involved in the suppressive effect of adiponectin on palmitate-induced ROS generation and apoptosis.

\section{Crosstalk between $C A M P / P K A$ and $A M P K$ pathways}

Crosstalk between cAMP/PKA and AMPK pathways was investigated, since both of these pathways mediate the inhibitory effect of adiponectin on palmitate-induced apoptosis. Pretreatment of cells with the AMPK inhibitor compound $\mathrm{C}$ blocked the inhibitory effect of forskolin on apoptosis as measured by caspase-3 activity and annexin $\mathrm{V}$ staining. In contrast, the cAMP inhibitor SQ22536 or PKA inhibitor H-89 did not block the inhibitory effect of AICAR on apoptosis (Fig. 6A and B). Furthermore, cells transfected with Ad-DN-AMPK blocked the inhibitory effect of both AICAR and forskolin on palmitate-induced apoptosis (Fig. 6C). Forskolin increased AMPK phosphorylation at Thr-172 and Ser-485/491. Forskolin-mediated activation of pAMPK at both the sites was blocked by the cAMP inhibitor SQ22536 or PKA inhibitor H-89 (Fig. 6D). These results suggest the possibility of crosstalk between cAMP/PKA and AMPK pathways. 

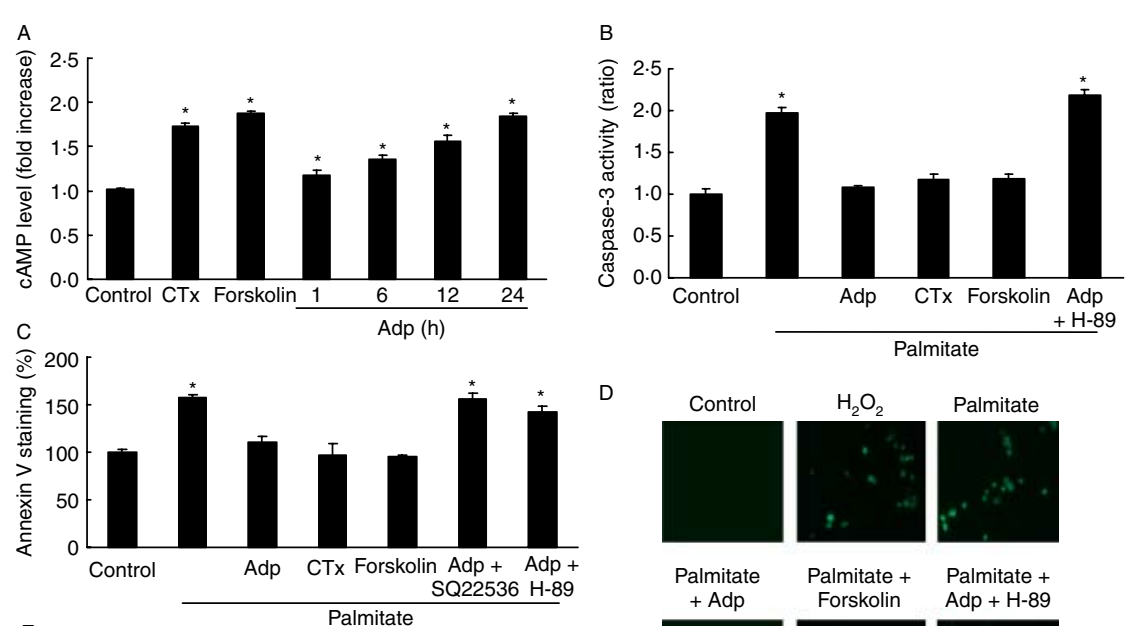

D
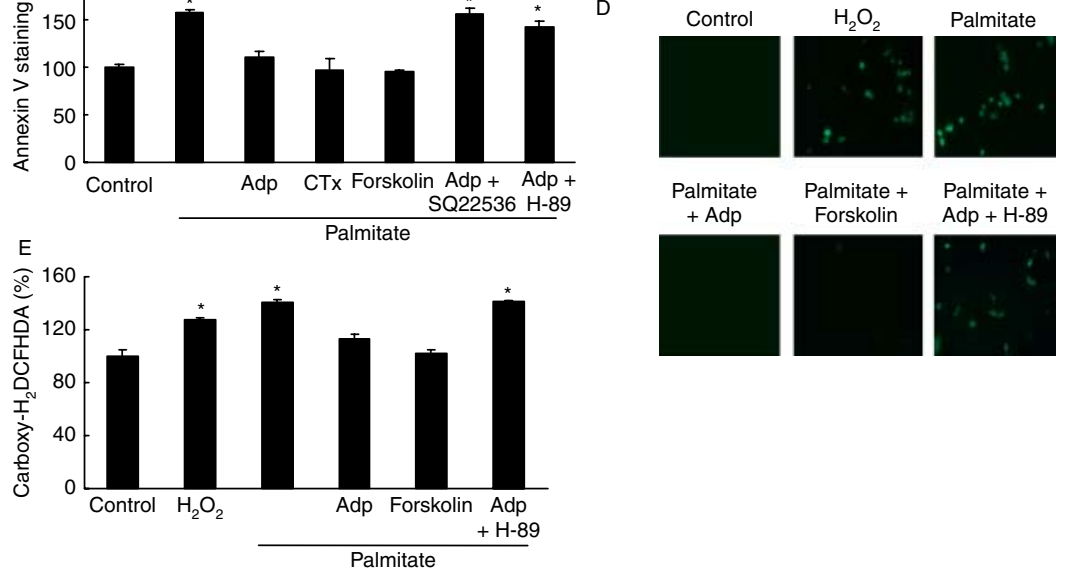

Figure 5 Involvement of cAMP/PKA pathway in the inhibitory effects of adiponectin on palmitate-induced ROS generation and apoptosis in human umbilical vein endothelial cells. Cells were treated with the cAMP activators cholera toxin $(\mathrm{CTx}, 200 \mathrm{ng} / \mathrm{ml})$ and forskolin $(10 \mu \mathrm{M})$ for $1 \mathrm{~h}$, and adiponectin (adp, $5 \mu \mathrm{g} / \mathrm{ml})$ for the indicated times. cAMP levels were determined by ELISA (A). Cells were treated with the CAMP inhibitor SQ22536 (50 $\mu \mathrm{M})$ or the PKA inhibitor $\mathrm{H}-89(10 \mu \mathrm{M})$ for $1 \mathrm{~h}$ and then with adiponectin $(5 \mu \mathrm{g} / \mathrm{ml})$, cholera toxin $(200 \mathrm{ng} / \mathrm{ml})$, or forskolin $(10 \mu \mathrm{M})$ for $1 \mathrm{~h}$ before exposure to $500 \mu \mathrm{M}$ palmitate for $48 \mathrm{~h}$. Cell apoptosis was determined by caspase-3 activity (B) and annexin $\mathrm{V}$ staining (C). Cells were treated with the PKA inhibitor $\mathrm{H}-89(10 \mu \mathrm{M})$ for $30 \mathrm{~min}$ and then with adiponectin $(5 \mu \mathrm{g} / \mathrm{ml})$ or forskolin $(10 \mu \mathrm{M})$ before exposure to $500 \mu \mathrm{M}$ palmitate for $18 \mathrm{~h}$. ROS was detected using $\mathrm{H}_{2}$ DCFHDA under microscope. Cells treated with $1 \mathrm{mM} \mathrm{H}_{2} \mathrm{O}_{2}$ were used as a positive control (D). ROS was detected using carboxy- $\mathrm{H}_{2}$ DCFHDA with flow cytometry analysis under same experimental conditions as in (D) except for the incubation time of palmitate $(6 \mathrm{~h})$. Cells treated with $1 \mathrm{mM} \mathrm{H}_{2} \mathrm{O}_{2}$ were used as a positive control (E). The results are reported as the mean \pm s.E.M. of three to five separate experiments. In each experiment, at least three samples were used. $* P<0 \cdot 05$ versus control.

\section{Discussion}

The present study demonstrates that adiponectin inhibits palmitate-induced apoptosis though the suppression of ROS generation. This suggests that adiponectin acts as an endogenous antioxidant and an anti-apoptotic agent against palmitate in endothelial cells. Both AMPK and cAMP/PKA are involved as signaling pathways.

Palmitate induces apoptosis in diverse cell types such as endothelial cells (Yamaguchi et al. 2002), cardiomyocytes (Sparagna et al. 2000), pancreatic $\beta$-cells (Kwon et al. 2004), testicular Leydig cells (Lu et al. 2003), human granulosa cells (Mu et al. 2001), bovine retinal pericytes (Cacicedo et al. 2005), skeletal muscle myotubes (Turpin et al. 2006), and human osteoblast cells (Kim et al. 2008b).
Although the mechanism by which palmitate induces apoptosis is not completely understood, overproduction of ROS has been suggested as one of the possible causes in several cell types including endothelial cells (Yamagishi et al. 2002, Yao et al. 2005). In this study, we also showed that palmitate induced apoptosis through ROS generation in HUVECs. Despite recent studies concerning the role of ROS as a signaling molecule (Avshalumov et al. 2007), the imbalance between detoxifying antioxidant system and ROS generation leads to divergent pathological disorders (Stocker \& Keaney 2004, Schulze \& Lee 2005, Takimoto \& Kass 2007). Accumulating evidence also indicates that ROS mediates endothelial cell apoptosis to many different stresses such as bacterial toxin, cytokine, and neuronal hormone (Deshpande et al. 2000, Suematsu et al. 2002, Sylte et al. 2004, Kuckleburg et al. 2008). 

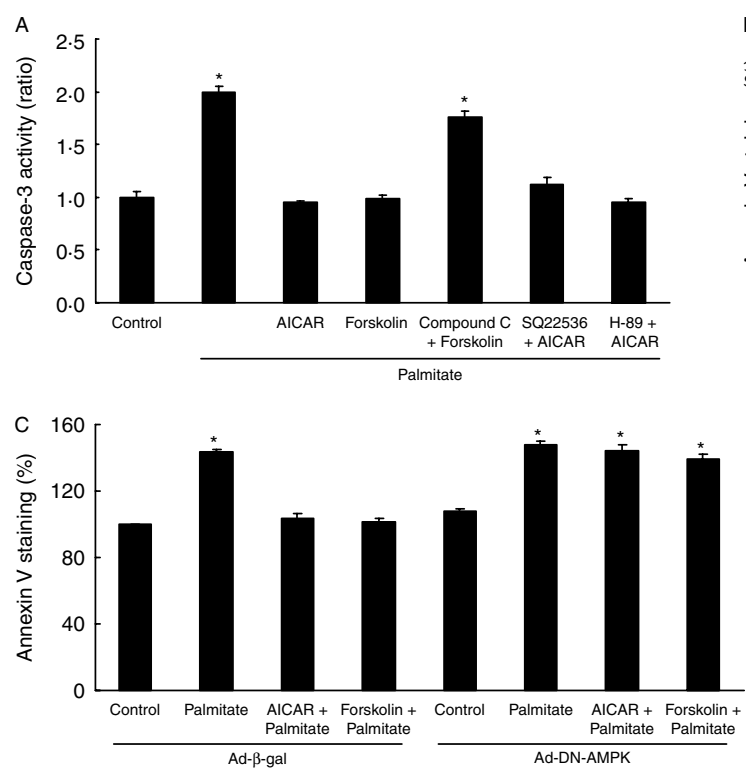
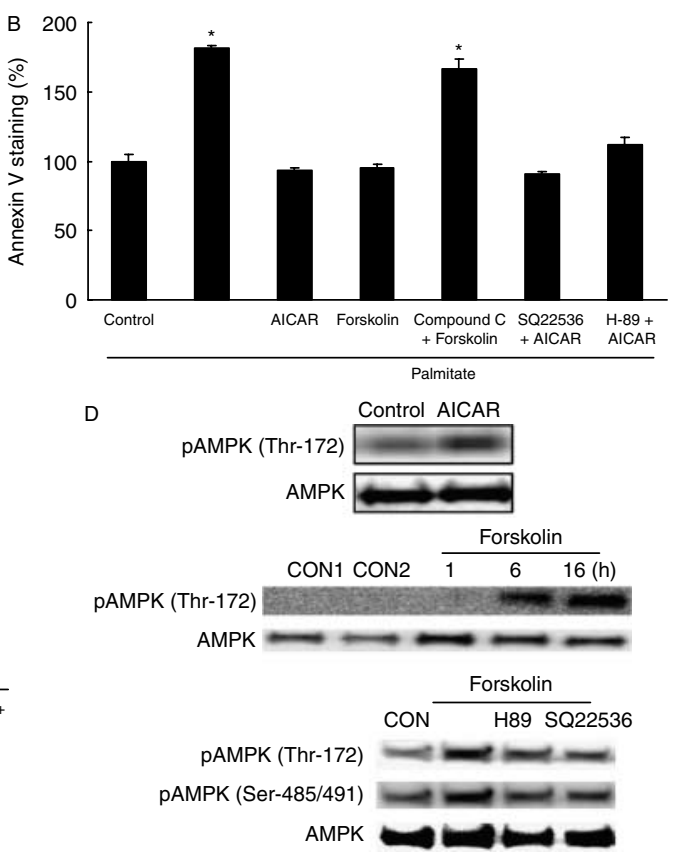

Figure 6 Crosstalk between AMPK and cAMP/PKA pathways in human umbilical vein endothelial cells. Cells were pretreated with compound C $(40 \mu \mathrm{M})$, SQ22536 $(50 \mu \mathrm{M})$, or $\mathrm{H}-89(10 \mu \mathrm{M})$ for 1 h before exposure to forskolin $(10 \mu \mathrm{M})$ or AICAR $(1 \mathrm{mM})$. After $1 \mathrm{~h}$, cells were treated with $500 \mu \mathrm{M}$ palmitate for $48 \mathrm{~h}$. Apoptosis was determined by caspase-3 activity (A) and annexin $V$ staining (B). Cells were transfected with 100 pfu/cell of adenovirus containing dominantnegative AMPK (Ad-DN-AMPK) or $\beta$-galactosidase (Ad- $\beta$-gal), and then pretreated with AICAR ( $1 \mathrm{mM})$ or forskolin $(10 \mu \mathrm{M})$ for $1 \mathrm{~h}$ before exposure to $500 \mu \mathrm{M}$ palmitate for $48 \mathrm{~h}(\mathrm{C})$. AICAR $(1 \mathrm{mM})$ was treated in untransfected cells for $1 \mathrm{~h}$, and forskolin $(10 \mu \mathrm{M})$ was treated for the indicated time. Phosphorylated AMPK at Thr-172 and Ser-485/491 was determined by western blotting (D). The results are reported as the mean \pm S.E.M. of three to five separate experiments. In each experiment, at least three samples were used. ${ }^{*} P<0 \cdot 05$ versus control.

The suppression of ROS generation by adiponectin is related to various beneficial effects. Adiponectin suppresses the ROS generation induced by hyperglycemia (Ouedraogo et al. 2006), oxidative low-density lipoprotein (Motoshima et al. 2004), 1-methyl-4-phenylpyridinium ion (Jung et al. 2006), acetaldehyde (Jung et al. 2006), and angiotensin II (Fujita et al. 2008), which leads to an anti-proliferative effect in endothelial cells (Motoshima et al. 2004), anti-apoptosis in a neuroblastoma cell line (Jung et al. 2006), and inhibits cardiac fibrosis (Fujita et al. 2008). Presently, adiponectin also suppressed the ROS production induced by palmitate, which resulted in increased endothelial cell survival. Endothelial cell apoptosis can induce vascular leakage and increase thrombogenesis, leading to vascular dysfunction (Winn \& Harlan 2005). Therefore, an anti-apoptotic effect of adiponectin against palmitate could be one of the mechanisms of vascular protection.

The signal transduction pathway mediating the antioxidant effect of adiponectin is a topic of intense research, and AMPK and cAMP pathways have been reported as possible candidates. AMPK is a serine/threonine protein kinase, which was first identified as an energy sensor that responds to reduced energy state such as glucose deprivation, hypoxia, and ischemia (Hardie 2003). Once activated, it switches off the ATP-consuming anabolic pathway and switches on the ATP-generating catabolic pathway (Hardie et al. 1998). Since its discovery, investigations into the effects of AMPK have shown that it also serves as an anti-inflammatory agent (Cacicedo et al. 2004, Ayasolla et al. 2005) and inhibits cell proliferation (Motoshima et al. 2006). Although AMPK increases oxidative stresses that lead to apoptosis in pancreatic $\beta$-cells (Cai et al. 2007, Kim et al. 2007), it plays an opposite role in endothelial cells. Activation of AMPK by the AMPK activator AICAR suppresses ROS generation (Kukidome et al. 2006). Moreover, AMPK functions as a signaling pathway of plasma hormones including adiponectin that activates AMPK in endothelial cells (Ouedraogo et al. 2006), cardiac fibroblast (Fujita et al. 2008), hepatic satellite cells (Adachi \& Brenner 2008), skeletal muscle (Yamauchi et al. 2002), and vascular smooth muscle cells (Son et al. 2008). In the current study, adiponectin also increased AMPK activity in HUVECs, and the antioxidant and anti-apoptotic effects of adiponectin were reversed by AMPK inhibition. These results indicate that AMPK plays a role as a signaling molecule in the adiponectin-mediated beneficial effects.

Recently, besides AMPK, the cAMP signaling pathway was also involved in a variety of adiponectin-mediated beneficial effects. cAMP is a ubiquitous second messenger that mediates 
the action of multiple hormones and neurotransmitters (Zaccolo et al. 2005), and PKA is considered the most important effector of cAMP (Taylor et al. 1992). Intracellular cAMP levels decrease under an oxygen free radical-generating system (Raynaud et al. 1997), and cAMP analogs display anti-apoptotic and antioxidant effects (Kim et al. 2002, Fujita et al. 2006). A substantial body of evidence suggests that adiponectin functions as an activator of cAMP in macrophages (Zhao et al. 2005) and endothelial cells (Ouedraogo et al. 2006, Chen et al. 2008). Moreover, adiponectinmediated activation of cAMP exerts antioxidative effects as well as anti-inflammatory and anti-atherosclerotic effects (Ouchi et al. 2000, Zhao et al. 2005, Ouedraogo et al. 2006, Chen et al. 2008). In the current study, adiponectin activated cAMP level in HUVECs, and the beneficial effect of adiponectin was reversed by the inhibitors of cAMP and PKA suggesting that the cAMP/PKA pathway also mediates the antioxidant and anti-apoptotic effects of adiponectin.

Interestingly, we observed that both the AMPK and cAMP/PKA pathways were effective as adiponectin mediators. This result suggests the possibility of an interaction between these two pathways, and cAMP seems to activate AMPK. The involvement of multiple pathways mediating the effect of adiponectin has also been documented previously. Both the pathways are comparably active in the attenuated activation of I $\kappa \beta$ kinase by tumor necrosis factor- $\alpha$, whereas AMPK is substantially more effective than cAMP in suppressing high glucose-induced I $\kappa \beta$ kinase activation in endothelial cells (Wu et al. 2007). Contrary to these results, the suppressive effect of adiponectin on high glucose-induced ROS generation can be effectively mediated through the cAMP/PKA-dependent pathway than via AMPK (Ouedraogo et al. 2006). However, these studies did not show the relation between these two pathways, although an interaction between cAMP/PKA and AMPK had previously been documented. Activation of cAMP by isoproterenol or forskolin or a cAMP analog increases AMPK activation in adipocytes, and the inhibition of AMPK significantly blocks cAMP-mediated lipolysis by isoproterenol (Yin et al. 2003). These results are consistent with our study showing that cAMP is an activator of AMPK activity. However, reduced AMPK activity by cAMP has also been documented. The activation of cAMP attenuates phosphorylation of Thr-172 leading to reduced AMPK activation in pancreatic INS-1 cells by phosphorylation of Ser-485/491 (Hurley et al. 2006). However, in our study, cAMP activation increased both the phosphorylation of Ser-485/491 and phosphorylation of Thr-172 suggesting that different effects of cAMP activation on the modulation of AMPK activity depend on the experimental setting and tissues. The mechanisms or signaling pathways responsible for connecting cAMP/PKA and AMPK pathways are currently unknown and require further study.

In conclusion, adiponectin suppresses palmitate-induced ROS generation and apoptosis. Even though AMPK pathway is involved directly, cAMP/PKA pathway also seems to contribute in the anti-apoptotic effect of adiponectin.
The suppression of cAMP-mediated antioxidant and anti-apoptotic effects by AMPK inhibition suggests a possible connection between these two pathways. Further studies are needed to ascertain the crosstalk between these pathways that could simplify adiponectin-mediated multiple and complicated signaling pathways.

\section{Declaration of interest}

The authors declare that there is no conflict of interest that could be perceived as prejudicing the impartiality of the research reported.

\section{Funding}

This work was supported by the Korea Science and Engineering Foundation (KOSEF) grant funded by the Korea government (2010-0007389 and R012007-000-20087-0).

\section{References}

Adachi M \& Brenner DA 2008 High molecular weight adiponectin inhibits proliferation of hepatic stellate cells via activation of adenosine monophosphate-activated protein kinase. Hepatology 47 677-685. (doi:10. 1002/hep.21991)

Arita Y, Kihara S, Ouchi N, Maeda K, Kuriyama H, Okamoto Y, Kumada M, Hotta K, Nishida M, Takahashi M et al. 2002 Adipocyte-derived plasma protein adiponectin acts as a platelet-derived growth factor-BB-binding protein and regulates growth factor-induced common postreceptor signal in vascular smooth muscle cell. Circulation 105 2893-2898. (doi:10.1161) 01.CIR.0000018622.84402.FF)

Avshalumov MV, Bao L, Patel JC \& Rice ME $2007 \mathrm{H}_{2} \mathrm{O}_{2}$ signaling in the nigrostriatal dopamine pathway via ATP-sensitive potassium channels: issues and answers. Antioxidants \& Redox Signaling 9 219-231. (doi:10.1089/ ars.2007.9.219)

Ayasolla KR, Singh AK \& Singh I 2005 5-Aminoimidazole-4-carboxamide$1-\beta$-4-ribofuranoside (AICAR) attenuates the expression of LPS- and A $\beta$ peptide-induced inflammatory mediators in astroglia. Journal of Neuroinflammation 2 21. (doi:10.1186/1742-2094-2-21)

Boden G \& Shulman GI 2002 Free fatty acids in obesity and type 2 diabetes: defining their role in the development of insulin resistance and $\beta$-cell dysfunction. European Journal of Clinical Investigation 32 (Suppl 3) 14-23. (doi:10.1046/j.1365-2362.32.s3.3.x)

Cacicedo JM, Yagihashi N, Keaney JF Jr, Ruderman NB \& Ido Y 2004 AMPK inhibits fatty acid-induced increases in NF-kappaB transactivation in cultured human umbilical vein endothelial cells. Biochemical and Biophysical Research Communications 324 1204-1209. (doi:10.1016/j.bbrc. 2004.09.177)

Cacicedo JM, Benjachareowong S, Chou E, Ruderman NB \& Ido Y 2005 Palmitate-induced apoptosis in cultured bovine retinal pericytes: roles of NAD(P)H oxidase, oxidant stress, and ceramide. Diabetes 54 1838-1845. (doi:10.2337/diabetes.54.6.1838)

Cai Y, Martens GA, Hinke SA, Heimberg H, Pipeleers D \& Van de Casteele M 2007 Increased oxygen radical formation and mitochondrial dysfunction mediate $\beta$ cell apoptosis under conditions of AMP-activated protein kinase stimulation. Free Radical Biology \& Medicine 42 64-78. (doi:10.1016/ j.freeradbiomed.2006.09.018)

Chen H, Montagnani M, Funahashi T, Shimomura I \& Quon MJ 2003 Adiponectin stimulates production of nitric oxide in vascular endothelial cells. Journal of Biological Chemistry 278 45021-45026. (doi:10.1074/jbc. M307878200) 
Chen YJ, Zhang LQ, Wang GP, Zeng H, Lu B, Shen XL, Jiang ZP \& Chen FP 2008 Adiponectin inhibits tissue factor expression and enhances tissue factor pathway inhibitor expression in human endothelial cells. Thrombosis and Haemostasis 100 291-300. (doi:10.1160/TH08-02-0124)

Deshpande SS, Angkeow P, Huang J, Ozaki M \& Irani K 2000 Rac1 inhibits TNF- $\alpha$-induced endothelial cell apoptosis: dual regulation by reactive oxygen species. FASEB Journal 14 1705-1714. (doi:10.1096/fj.99-0910com)

Fujita H, Ogino T, Kobuchi H, Fujiwara T, Yano H, Akiyama J, Utsumi K \& Sasaki J 2006 Cell-permeable cAMP analog suppresses 6-hydroxydopamine-induced apoptosis in PC12 cells through the activation of the Akt pathway. Brain Research 1113 10-23. (doi:10.1016/ j.brainres.2006.06.079)

Fujita K, Maeda N, Sonoda M, Ohashi K, Hibuse T, Nishizawa H, Nishida M, Hiuge A, Kurata A, Kihara S et al. 2008 Adiponectin protects against angiotensin II-induced cardiac fibrosis through activation of PPAR- $\alpha$. Arteriosclerosis, Thrombosis, and Vascular Biology 28 863-870. (doi:10.1161/ ATVBAHA.107.156687)

Fulda S \& Debatin KM 2006 Resveratrol modulation of signal transduction in apoptosis and cell survival: a mini-review. Cancer Detection and Prevention 30 217-223. (doi:10.1016/j.cdp.2006.03.007)

Goldstein BJ, Scalia RG \& Ma XL 2008 Protective vascular and myocardial effects of adiponectin. Nature Clinical Practice. Cardiovascular Medicine 6 27-35. (doi:10.1038/ncpcardio1398)

Haluzik M, Parizkova J \& Haluzik MM 2004 Adiponectin and its role in the obesity-induced insulin resistance and related complications. Physiological Research 53 123-129.

Han SH, Quon MJ, Kim JA \& Koh KK 2007 Adiponectin and cardiovascular disease: response to therapeutic interventions. Journal of the American College of Cardiology 49 531-538. (doi:10.1016/j.jacc.2006.08.061)

Hardie DG 2003 Minireview: the AMP-activated protein kinase cascade: the key sensor of cellular energy status. Endocrinology 144 5179-5183. (doi:10. 1210/en.2003-0982)

Hardie DG, Carling D \& Carlson M 1998 The AMP-activated/SNF1 protein kinase subfamily: metabolic sensors of the eukaryotic cell? Annual Review of Biochemistry 67 821-855. (doi:10.1146/annurev.biochem.67.1.821)

Hurley RL, Barre LK, Wood SD, Anderson KA, Kemp BE, Means AR \& Witters LA 2006 Regulation of AMP-activated protein kinase by multisite phosphorylation in response to agents that elevate cellular cAMP. Journal of Biological Chemistry 281 36662-36672. (doi:10.1074/jbc.M606676200)

Jung TW, Lee JY, Shim WS, Kang ES, Kim JS, Ahn CW, Lee HC \& Cha BS 2006 Adiponectin protects human neuroblastoma SH-SY5Y cells against acetaldehyde-induced cytotoxicity. Biochemical Pharmacology 72 616-623. (doi:10.1016/j.bcp.2006.05.013)

Kim EJ, Kwon KJ, Park JY, Lee SH, Moon CH \& Baik EJ 2002 Neuroprotective effects of prostaglandin $\mathrm{E}_{2}$ or cAMP against microglial and neuronal free radical mediated toxicity associated with inflammation. Journal of Neuroscience Research 70 97-107. (doi:10.1002/jnr.10373)

Kim WH, Lee JW, Suh YH, Lee HJ, Lee SH, Oh YK, Gao B \& Jung MH 2007 AICAR potentiates ROS production induced by chronic high glucose: roles of AMPK in pancreatic $\beta$-cell apoptosis. Cellular Signalling 19 791-805. (doi:10.1016/j.cellsig.2006.10.004)

Kim HS, Hwang JT, Yun H, Chi SG, Lee SJ, Kang I, Yoon KS, Choe WJ, Kim SS \& Ha J 2008a Inhibition of AMP-activated protein kinase sensitizes cancer cells to cisplatin-induced apoptosis via hyper-induction of $\mathrm{p} 53$. Journal of Biological Chemistry 283 3731-3742. (doi:10.1074/jbc. M704432200)

Kim JE, Ahn MW, Baek SH, Lee IK, Kim YW, Kim JY, Dan JM \& Park SY 2008b AMPK activator AICAR inhibits palmitate-induced apoptosis in osteoblast. Bone 43 394-404. (doi:10.1016/j.bone.2008.03.021)

Kim JE, Kim YW, Lee IK, Kim JY, Kang YJ \& Park SY 2008c AMP-activated protein kinase activation by 5 -aminoimidazole-4-carboxamide$1-\beta$-D-ribofuranoside (AICAR) inhibits palmitate-induced endothelial cell apoptosis through reactive oxygen species suppression. Journal of Pharmacological Sciences 106 394-403. (doi:10.1254/jphs.FP0071857)

Kong JY \& Rabkin SW 2000 Palmitate-induced apoptosis in cardiomyocytes is mediated through alterations in mitochondria: prevention by cyclosporin A. Biochimica et Biophysica Acta 1485 45-55. (doi:10.1016/S13881981(00)00028-7)
Kougias P, Chai H, Lin PH, Yao Q, Lumsden AB \& Chen C 2005 Effects of adipocyte-derived cytokines on endothelial functions: implication of vascular disease. Journal of Surgical Research 126 121-129. (doi:10.1016/j.jss. 2004.12.023)

Kuckleburg CJ, Tiwari R \& Czuprynski CJ 2008 Endothelial cell apoptosis induced by bacteria-activated platelets requires caspase- 8 and -9 and generation of reactive oxygen species. Thrombosis and Haemostasis 99 363-372. (doi:10.1160/TH07-07-0474)

Kukidome D, Nishikawa T, Sonoda K, Imoto K, Fujisawa K, Yano M, Motoshima H, Taguchi T, Matsumura T \& Araki E 2006 Activation of AMP-activated protein kinase reduces hyperglycemia-induced mitochondrial reactive oxygen species production and promotes mitochondrial biogenesis in human umbilical vein endothelial cells. Diabetes 55 120-127. (doi:10.2337/diabetes.55.01.06.db05-0943)

Kwon G, Pappan KL, Marshall CA, Schaffer JE \& McDaniel ML 2004 cAMP dose-dependently prevents palmitate-induced apoptosis by both protein kinase A- and cAMP-guanine nucleotide exchange factor-dependent pathways in $\beta$-cells. Journal of Biological Chemistry 279 8938-8945. (doi:10. 1074/jbc.M310330200)

Lee M, Hwang JT, Lee HJ, Jung SN, Kang I, Chi SG, Kim SS \& Ha J 2003 AMP-activated protein kinase activity is critical for hypoxia-inducible factor- 1 transcriptional activity and its target gene expression under hypoxic conditions in DU145 cells. Journal of Biological Chemistry 278 39653-39661. (doi:10.1074/jbc.M306104200)

Lee WJ, Lee IK, Kim HS, Kim YM, Koh EH, Won JC, Han SM, Kim MS, Jo I, Oh GT et al. 2005 Alpha-lipoic acid prevents endothelial dysfunction in obese rats via activation of AMP-activated protein kinase. Atteriosclerosis, Thrombosis, and Vascular Biology 25 2488-2494. (doi:10.1161/01.ATV. 0000190667.33224.4c)

Lu ZH, Mu YM, Wang BA, Li XL, Lu JM, Li JY, Pan CY, Yanase T \& Nawata H 2003 Saturated free fatty acids, palmitic acid and stearic acid, induce apoptosis by stimulation of ceramide generation in rat testicular Leydig cell. Biochemical and Biophysical Research Communications 303 1002-1007. (doi:10.1016/S0006-291X(03)00449-2)

Maeda N, Shimomura I, Kishida K, Nishizawa H, Matsuda M, Nagaretani H, Furuyama N, Kondo H, Takahashi M, Arita Y et al. 2002 Diet-induced insulin resistance in mice lacking adiponectin/ACRP30. Nature Medicine 8 731-737. (doi:10.1038/nm724)

Matsuzawa Y 2005 Adiponectin: identification, physiology and clinical relevance in metabolic and vascular disease. Atherosclerosis. Supplements 6 7-14. (doi:10.1016/j.atherosclerosissup.2005.02.003)

Motoshima H, Wu X, Mahadev K \& Goldstein BJ 2004 Adiponectin suppresses proliferation and superoxide generation and enhances eNOS activity in endothelial cells treated with oxidized LDL. Biochemical and Biophysical Research Communications 315 264-271. (doi:10.1016/j.bbrc. 2004.01.049)

Motoshima H, Goldstein BJ, Igata M \& Araki E 2006 AMPK and cell proliferation - AMPK as a therapeutic target for atherosclerosis and cancer. Journal of Physiology 574 63-71. (doi:10.1113/jphysiol.2006.108324)

Mu YM, Yanase T, Nishi Y, Tanaka A, Saito M, Jin CH, Mukasa C, Okabe T, Nomura M, Goto K et al. 2001 Saturated FFAs, palmitic acid and stearic acid, induce apoptosis in human granulosa cells. Endocrinology 142 3590-3597. (doi:10.1210/en.142.8.3590)

Ouchi N, Kihara S, Arita Y, Okamoto Y, Maeda K, Kuriyama H, Hotta K, Nishida M, Takahashi M, Muraguchi M et al. 2000 Adiponectin, an adipocyte-derived plasma protein, inhibits endothelial NF-kappaB signaling through a cAMP-dependent pathway. Circulation 102 1296-1301.

Ouchi N, Kihara S, Arita Y, Nishida M, Matsuyama A, Okamoto Y, Ishigami M, Kuriyama H, Kishida K, Nishizawa H et al. 2001 Adipocyte-derived plasma protein, adiponectin, suppresses lipid accumulation and class A scavenger receptor expression in human monocyte-derived macrophages. Circulation 103 1057-1063.

Ouedraogo R, Wu X, Xu SQ, Fuchsel L, Motoshima H, Mahadev K, Hough K, Scalia R \& Goldstein BJ 2006 Adiponectin suppression of high-glucose-induced reactive oxygen species in vascular endothelial cells: evidence for involvement of a cAMP signaling pathway. Diabetes $\mathbf{5 5}$ 1840-1846. (doi:10.2337/db05-1174) 
Raynaud F, Evain-Brion D, Gerbaud P, Marciano D, Gorin I, Liapi C \& Anderson WB 1997 Oxidative modulation of cyclic AMP-dependent protein kinase in human fibroblasts: possible role in psoriasis. Free Radical Biology \& Medicine 22 623-632. (doi:10.1016/S0891-5849(96)00353-X)

Ruderman NB \& Saha AK 2006 Metabolic syndrome: adenosine monophosphate-activated protein kinase and malonyl coenzyme A. Obesity 14 (Suppl 1) 25S-33S. (doi:10.1038/oby.2006.279)

Schulze PC \& Lee RT 2005 Oxidative stress and atherosclerosis. Current Atherosclerosis Reports 7 242-248. (doi:10.1007/s11883-005-0013-5)

Shulman GI 2000 Cellular mechanisms of insulin resistance. Journal of Clinical Investigation 106 171-176. (doi:10.1172/JCI10583)

Son BK, Akishita M, Iijima K, Kozaki K, Maemura K, Eto M \& Ouchi Y 2008 Adiponectin antagonizes stimulatory effect of tumor necrosis factor- $\alpha$ on vascular smooth muscle cell calcification: regulation of growth arrest-specific gene 6-mediated survival pathway by adenosine 5'-monophosphate-activated protein kinase. Endocrinology 149 1646-1653. (doi:10.1210/en.2007-1021)

Sparagna GC, Hickson-Bick DL, Buja LM \& McMillin JB 2000 A metabolic role for mitochondria in palmitate-induced cardiac myocyte apoptosis. American Journal of Physiology. Heart and Circulatory Physiology 279 H2124-H2132.

Stocker R \& Keaney JFJr 2004 Role of oxidative modifications in atherosclerosis. Physiological Reviews 84 1381-1478. (doi:10.1152/physrev.00047.2003)

Suematsu M, Suzuki H, Delano FA \& Schmid-Schonbein GW 2002 The inflammatory aspect of the microcirculation in hypertension: oxidative stress, leukocytes/endothelial interaction, apoptosis. Microcirculation 9 259-276. (doi:10.1038/sj.mn.7800141)

Sylte MJ, Inzana TJ \& Czuprynski CJ 2004 Reactive oxygen and nitrogen intermediates contribute to Haemophilus somnus lipooligosaccharidemediated apoptosis of bovine endothelial cells. Veterinary Immunology and Immunopathology 97 207-217. (doi:10.1016/j.vetimm.2003.09.005)

Takimoto E \& Kass DA 2007 Role of oxidative stress in cardiac hypertrophy and remodeling. Hypertension 49 241-248. (doi:10.1161/01.HYP. 0000254415.31362.a7)

Tan KC, Xu A, Chow WS, Lam MC, Ai VH, Tam SC \& Lam KS 2004 Hypoadiponectinemia is associated with impaired endothelium-dependent vasodilation. Journal of Clinical Endocrinology and Metabolism 89 765-769. (doi:10.1210/jc.2003-031012)

Taylor SS, Knighton DR, Zheng J, Ten Eyck LF \& Sowadski JM 1992 Structural framework for the protein kinase family. Annual Review of Cell Biology 8 429-462. (doi:10.1146/annurev.cb.08.110192.002241)

Turpin SM, Lancaster GI, Darby I, Febbraio MA \& Watt MJ 2006 Apoptosis in skeletal muscle myotubes is induced by ceramides and is positively related to insulin resistance. American Journal of Physiology. Endocrinology and Metabolism 291 E1341-E1350. (doi:10.1152/ajpendo. 00095.2006) de Vries JE, Vork MM, Roemen TH, de Jong YF, Cleutjens JP, van der Vusse GJ \& van Bilsen M 1997 Saturated but not mono-unsaturated fatty acids induce apoptotic cell death in neonatal rat ventricular myocytes. Journal of Lipid Research 38 1384-1394.

Winn RK \& Harlan JM 2005 The role of endothelial cell apoptosis in inflammatory and immune diseases. Journal of Thrombosis and Haemostasis 3 1815-1824. (doi:10.1111/j.1538-7836.2005.01378.x)

Wu X, Mahadev K, Fuchsel L, Ouedraogo R, Xu SQ \& Goldstein BJ 2007 Adiponectin suppresses IkappaB kinase activation induced by tumor necrosis factor- $\alpha$ or high glucose in endothelial cells: role of cAMP and AMP kinase signaling. American Journal of Physiology. Endocrinology and Metabolism 293 E1836-E1844. (doi:10.1152/ajpendo.00115.2007)

Yamagishi S, Okamoto T, Amano S, Inagaki Y, Koga K, Koga M, Choei H, Sasaki N, Kikuchi S, Takeuchi M et al. 2002 Palmitate-induced apoptosis of microvascular endothelial cells and pericytes. Molecular Medicine 8 179-184.

Yamaguchi T, Sugimoto T, Yano S, Yamauchi M, Sowa H, Chen Q \& Chihara K 2002 Plasma lipids and osteoporosis in postmenopausal women. Endocrine Journal 49 211-217. (doi:10.1507/endocrj.49.211)

Yamauchi T, Kamon J, Minokoshi Y, Ito Y, Waki H, Uchida S, Yamashita S, Noda M, Kita S, Ueki K et al. 2002 Adiponectin stimulates glucose utilization and fatty-acid oxidation by activating AMP-activated protein kinase. Nature Medicine 8 1288-1295. (doi:10.1038/nm788)

Yao D, Shi W, Gou Y, Zhou X, Yee Aw T, Zhou Y \& Liu Z 2005 Fatty acid-mediated intracellular iron translocation: a synergistic mechanism of oxidative injury. Free Radical Biology \& Medicine 39 1385-1398. (doi:10.1016/j.freeradbiomed.2005.07.015)

Yin W, Mu J \& Birnbaum MJ 2003 Role of AMP-activated protein kinase in cyclic AMP-dependent lipolysis in 3T3-L1 adipocytes. Journal of Biological Chemistry 278 43074-43080. (doi:10.1074/jbc.M308484200)

Zaccolo M, Cesetti T, Di Benedetto G, Mongillo M, Lissandron V, Terrin A \& Zamparo I 2005 Imaging the cAMP-dependent signal transduction pathway. Biochemical Society Transactions 33 1323-1326. (doi:10.1042/ BST20051323)

Zhao T, Hou M, Xia M, Wang Q, Zhu H, Xiao Y, Tang Z, Ma J \& Ling W 2005 Globular adiponectin decreases leptin-induced tumor necrosis factor- $\alpha$ expression by murine macrophages: involvement of cAMP-PKA and MAPK pathways. Cellular Immunology 238 19-30. (doi:10.1016/ j.cellimm.2005.12.002)

Received in final form 28 June 2010

Accepted 19 July 2010

Made available online as an Accepted Preprint 30 July 2010 